\title{
Ketorolac Ester Enhancer-prodrugs: Preparation and Evaluation of Their Physicochemical Properties
}

\author{
Sung-Il Yun ${ }^{1}$, Jung Sun Kim ${ }^{1,2 \dagger}$ and Chul Soon Yong ${ }^{3 \dagger}$ \\ ${ }^{1}$ Department of Biotechnology, Dongseo University, Busan 617-716, South Korea \\ ${ }^{2}$ Department of Biomedical Laboratory Science, Division of Health Science, Dongseo University, Busan 617-716, South Korea \\ ${ }^{3}$ College of Pharmacy, Yeungnam University, Gyongsan 1712-1749, South Korea \\ (Received November 30, $2008 \cdot$ Revised December 3, $2008 \cdot$ Accepted December 8, 2008)
}

\begin{abstract}
Six ester analogues of Ketorolac were synthesized as potential enhancer prodrugs for transdermal delivery. Solubility of these esters was determined in $10 \%$ propylene glycol (PG)/isotonic phosphate buffer (IPB) at room temperature while lipophilicity was obtained as partition coefficients $(\log P)$ and capacity factors $\left(\mathrm{k}^{\prime}\right)$ using HPLC. Stability of the prodrugs in skin extract and in plasma was investigated at $37^{\circ} \mathrm{C}$. The lipophilicity of the potential prodrugs increased in proportion to their alkyl chain length. Good linear relationship between partition coefficients $(\log P)$ and capacity factors (log k') was observed $\left(R^{2}=0.9961\right)$. All of the analogues were fairly stable but slowly degraded in IPB over a 12 hour period. However, their stability in skin extract and in plasma varied with most compounds gradually decomposing over a 12 hour period. Although unsaturation of the alkyl ester chain did not alter the over all lipophilicity of the compound, the half-life was significantly affected. In plasma, degradation of the esters was slower than in the skin extract, which is a desirable trait for enhancer-prodrugs. However, the overall hydrolysis in the skin extract needs to be facilitated for the development of an effective enhancer prodrug. The analogue with the shortest half life in the skin extract was the unsaturated C-12 analogue of $0.96 \mathrm{hr}$.
\end{abstract}

Key words - Ketorolac ester enhancer prodrug, SAR, Physicochemical properties

Ketorolac [( \pm )-5-benzoyl-2,3-dihydro-1H-pyrrolizine-1-carboxylic acid] is a nonsteroidal agent with potent analgesic and moderate anti-inflammatory activity (Table I). It is known to inhibit the synthesis of prostaglandins. Clinical studies with Ketorolac indicated a single-dose efficacy greater than that of morphine, meperidine and pentazocine in moderate to severe post-operative pain. ${ }^{1-3)}$ Unlike other narcotic analgesics, Ketorolac does not have potential addiction problems and respiratory depression. Therefore, it is a relatively more favorable therapeutic agent for the management of post-operative pain. Although its oral bioavailability is reported to be $90 \%$ with a very low hepatic first-pass metabolism, frequent dosing is required to maintain the therapeutic effect due to its short biological half-life. ${ }^{3)}$ Moreover, long term use of its currently available dosage forms may result in gastrointestinal ulceration and acute renal failure. ${ }^{4)}$

Transdermal delivery of Ketorolac may reduce the side effects associated with oral administration, and can maintain constant therapeutic blood level for longer duration. Although

†본 논문에 관한 문의는 이 저자에게로

Tel : 051)320-1798, E-mail : jsk@gdsu.dongseo.ac.kr (JSK)

Tel : 053)810-2813, E-mail : csyong@ynu.ac.kr (CSY) several attempts have been reported to develop its transdermal delivery system using permeation enhancers, vehicles and ionotophoresis, these approaches may not have been very successful because of the inherently low lipophilicity of Ketorolac itself. $^{5-7)}$ Its $\log P$ value is reported to be only 1.04 , which is a value too low in terms of lipophilicity to allow passage through the lipid bilayer of the stratum corneum. ${ }^{8}$ )

Drug permeation through the stratum corneum can be increased with skin permeation enhancers. Practical use of enhancers requires the careful balancing of skin toxicity and the permeation enhancement benefit. ${ }^{9)}$ Oleic acid is one such penetration enhancers that have been demonstrated to increase the flux of exogenous additives through the stratum corneum in vitro. ${ }^{10)}$

Another approach is to transform the drug into prodrugs. A prodrug is a compound that undergoes transformation within the body before eliciting its therapeutic action and has been utilized widely since the late 1950 s for increasing drug bioavailability as well as drug targeting after oral administration. ${ }^{11)}$ This strategy is based on chemically modifying an active substance by attaching pro-moieties to pharmacophores, which ideally should overcome the biochemical and physical barriers impeding drug transport of the parent substance. Enhancer-prodrug is a new concept combining the enhancer 
method and the prodrug approach. By attaching the enhancer to the parent drug, toxicity due to the enhancer may be minimized. The ester bond formed by the drug enhancer would be cleaved in the skin by the esterases, after which the enhancer would help the permeation of drug through the skin.

In this study, an attempt has been made to synthesize enhancer-prodrugs of Ketorolac. Shorter alkyl chains attached by ester bondage have been reported by Roy $^{12)}$ et al. The elongation of the alkyl moieties of these short chained ester prodrugs brought about an increase in lipophilicity, increasing the skin permeation of Ketorolac. A similar study was also reported by $\mathrm{Doh}^{8)}$ et al. The limitation of these studies was in the fact that elongation of the ester alkyl chain longer than C3 unit resulted in a decrease in permeation. Moreover, the instability of the ester bondage could cause a problem in stability because the ester had to be intact until the prodrug passed through the stratum corneum.

An alternative therefore was proposed to apply a weak ester bond, which would be allowed to cleave before penetrating the stratum corneum. Herein we report on a systematic investigation of a series of Ketorolac oleate analogues, as potential enhancer-prodrugs for transdermal delivery. The compounds have been evaluated to determine the relationship between their physico-chemical properties and feasibility as enhancerprodrugs.

\section{Materials and Methods}

\section{Chemicals and Reagents}

Ketorolac sodium was purchased from Fluka (Sleeze, Germany). All reagents used to synthesize the analogues were purchased from Aldrich Chem. Co. Silica gel plate (Merck 60 $\mathrm{F}_{254}$ ) was used for thin layer chromatography (TLC). For column chromatography, Merck 60 silica gel $(0.063 \sim 0.200 \mathrm{~mm})$ and HPLC grade solvents were used. Infrared spectral data (IR) were obtained on a Mattson 3000 Fourier Transform spectrometer and are reported in $\mathrm{cm}^{-1}$. Proton $\left({ }^{1} \mathrm{H} \mathrm{NMR}\right)$ and carbon $\left({ }^{13} \mathrm{C} \mathrm{NMR}\right)$ nuclear magnetic resonance were recorded on a Varian Gemini $2000\left(300 \mathrm{MHz}{ }^{1} \mathrm{H}\right.$ and $\left.75 \mathrm{MHz}{ }^{13} \mathrm{C}\right)$ in the deuterated solvent indicated with chemical shifts reported in parts per million $(\delta)$ units downfield from tetramethylsilane (TMS) and ${ }^{1} \mathrm{H}$ NMR signals were quoted as s (singlet), $\mathrm{d}$ (doublet), $\mathrm{t}$ (triplet), and $\mathrm{m}$ (multiplet). Coupling constants are reported in hertz $(\mathrm{Hz})$. Low resolution Mass spectrum and High resolution Mass spectrum are reported in output $\mathrm{m} / \mathrm{z}$ range. NMR and Mass analysis were performed at the Korea Basic Science Institute. Ultraviolet spectra were recorded on an Optizen 2120 UV/VIS spectrometer. HPLC analyses were performed with a Waters 2690 HPLC equipped with UV. Mobile phase was prepared by filtering through a membrane filter ("Pall corporation", $47 \mathrm{~mm}, 0.45 \mu \mathrm{m}$ ) and degassed in an ultrasonicator (8510 Branson) before use.

\section{Synthesis of Ketorolac ester prodrugs}

Ketorolac sodium ( $880 \mathrm{mg}, 3.17 \mathrm{~m} \mathrm{~mol}$ ) was dissolved in water and acidified with $1 \mathrm{~N}-\mathrm{HCl}$ to give a suspension, which was collected by extraction in ethyl acetate to give Ketorolac free acid as a white solid (636 mg, 78.5\%) and used for the syntheses of ester prodrugs.

Ketorolac ester prodrugs were synthesized by adding $N, N$ 'dicyclohexylcarbodiimide (DCC) to Ketorolac together with the corresponding alcohols in the presence of 4-pyrrolidinopyridine, as shown in Scheme 1. ${ }^{8,13)}$ Table I shows the structures of analogues prepared for the current study.

\section{Determination of capacity factor ( $k$ ')}

The capacity factor, k', of Ketorolac and its ester prodrugs were determined by HPLC. A chromolith ${ }^{\mathrm{TM}}$ column (Lichrospher $125 * 4 \mathrm{~mm}, 5 \mu \mathrm{m}$ particle size, RP-8, Merck, Germany) was used as an alytical column at ambient temperature. The mobile phase was $90 \%$ methanol in $0.1 \mathrm{mM}$ acetate buffer, $\mathrm{pH}$ 4.7. The ratio of mobile phase composition was controlled to accommodate the different retention times of prodrugs. The flow rate of the mobile phase was $1.0 \mathrm{~mL} / \mathrm{min}$ and all samples to be analyzed were injected at a volume of $20 \mu \mathrm{L}$. The variable wavelength UV detector (Waters 2487 Dual $\lambda$ Absorbance Detector) was set at $314 \mathrm{~nm}$. The mobile phase hold-up time $\left(t_{0}\right)$ was determined by injecting the mobile phase. Each<smiles>[R2]C(=O)C1CCn2c(C(=O)c3ccccc3)ccc21</smiles>

Ketorolac

(DCC :Dicyclohexylcarbodiimide)

Scheme 1-Synthesis of Ketorolac ester prodrugs ${ }^{8,13)}$ 
Table I-Chemical Structures and Yields of Ketorolac and Its Ester Analogues

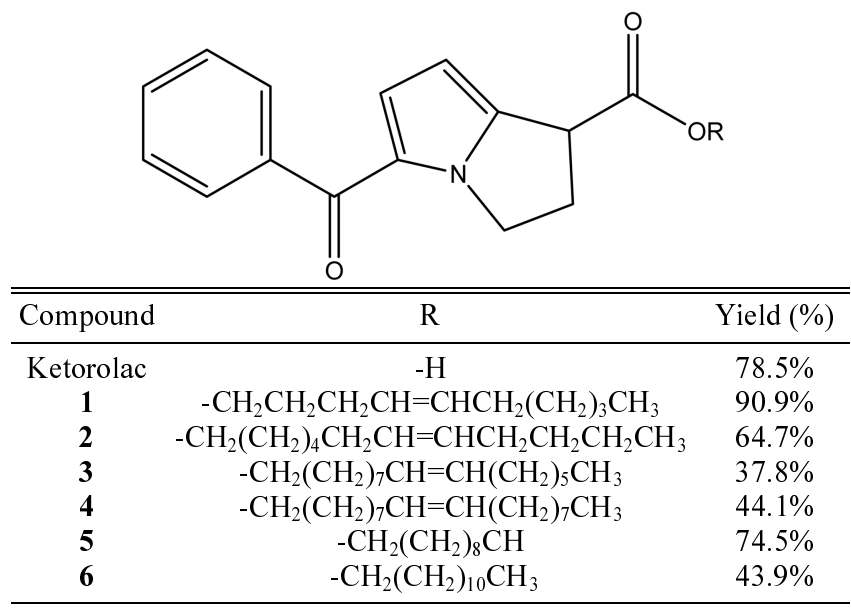

sample was injected three times and the average of the three retention times $\left(t_{R}\right)$ were used in calculating the capacity factor $\left(\mathrm{k}^{\prime}\right)$, from the equation below. ${ }^{14)}$

$$
\begin{aligned}
& \mathrm{k}^{\prime}=\left(\mathrm{t}_{\mathrm{R}}-\mathrm{t}_{0}\right) / \mathrm{t}_{0} \\
& \mathrm{t}_{\mathrm{R}} \text { : Retention time } \\
& \mathrm{t}_{0} \text { : Dead time of methanol }
\end{aligned}
$$

\section{Determination of solubility}

Each compound was added in excess to $1 \mathrm{~mL} 10 \% \mathrm{PG} / \mathrm{IPB}$ and shaken at room temperature for about $10 \mathrm{~min}$ to reach saturation. The saturated solutions were then filtered through Ministart RC 4 filters ( $0.45 \mu \mathrm{m}$, Sartorius, Germany) and analyzed by HPLC after appropriate dilution with methanol.

\section{Stability study of Ketorolac ester prodrugs}

Stability studies were conducted to confirm the conversion of various Ketorolac ester prodrugs. The stability of Ketorolac ester prodrugs in $10 \% \mathrm{PG} / \mathrm{IPB}$, skin extract and plasma, each at $37^{\circ} \mathrm{C}$ was investigated. Skin extract and plasma were obtained as previously described. ${ }^{8)}$ Based on the solubility study result, each Ketorolac ester prodrug was spiked to make $3 \mu \mathrm{g} / \mathrm{mL}$ (compound 1), $5 \mu \mathrm{g} / \mathrm{mL}$ (compound 2), $5 \mu \mathrm{g} / \mathrm{mL}$ (compound 3), $0.5 \mu \mathrm{g} / \mathrm{mL}$ (compound 4), $6 \mu \mathrm{g} / \mathrm{mL}$ (compound 5) and $6 \mu \mathrm{g} / \mathrm{mL}$ (compound 6) concentrations. The solutions were placed in a shaker (Shaking Incubator HB-201SF, $150 \mathrm{rpm}$ ) at $37^{\circ} \mathrm{C}$ for $12 \mathrm{hrs}$. At different time course $100 \mu \mathrm{L}$ was taken out to be analyzed by HPLC.

\section{Results and Discussion}

\section{Chemical synthesis and yield of enhancer prodrugs}

As shown in Table I, six enhancer-prodrug candidates have been synthesized in good yield (37.8 90.9\%). The longer carbon chained analogues were obtained at lower yields most probably because the product was poorly soluble in the solvent used for synthesis.

5-Benzoyl-2,3-dihydro-1H-pyrrolizine-1-carboxylic acid cis-4-decenate, Y-001 (1)

Ketorolac (2 g, $7.84 \mathrm{mmol})$ in $\mathrm{CH}_{2} \mathrm{Cl}_{2}(50 \mathrm{~mL}), N, N$ '-dicyclohexylcarbodiimide (1.0 M in $\mathrm{CH}_{2} \mathrm{Cl}_{2}, 9.7 \mathrm{mmol}$ ) and 4-pyrrolidinopyridine $(24 \mathrm{mg})$ and cis-4-decen-1-ol (3.62 g, 23.7 $\mathrm{mmol})$ gave the cis-4-decen-1-ester prodrug $(2.8 \mathrm{~g}, 90.9 \%)$ as a yellowish oil: UV (MeOH) $\lambda_{\max } 313 \mathrm{~nm}\left(\log \varepsilon_{\max }=4.01\right) ;{ }^{1} \mathrm{H}$ NMR (300 MHz, CD $\left.\mathrm{CD}_{3} \mathrm{OD}\right) \delta$ 7.82-7.42 (5H, m, Ar-H), 6.78 $(1 \mathrm{H}, \mathrm{d}, J=4.0 \mathrm{~Hz}, \mathrm{CH}=\mathrm{CH}), 6.08(1 \mathrm{H}, \mathrm{d}, J=4.0 \mathrm{~Hz}, \mathrm{CH}=$ $\mathrm{CH})$, 5.38-5.35 (2H, m, $\mathrm{CH}=\mathrm{CH}), 4.52-4.38\left(2 \mathrm{H}, \mathrm{m},-\mathrm{NCH}_{2}-\right)$, 4.08-4.06 (2H, m, $\mathrm{OCH}_{2}$ ), 4.04-4.00 (1H, m, -CH-), 2.88-2.68 $\left(2 \mathrm{H}, \mathrm{m},-\mathrm{CH}_{2^{-}}\right), 2.02-2.13\left(4 \mathrm{H}, \mathrm{m},-\mathrm{CH}_{2}-\right), 1.00-1.80(8 \mathrm{H}, \mathrm{m}$, $\left.-\mathrm{CH}_{2}-\right)$, 0.86-0.92 (3H, t, $\left.J=7.4 \mathrm{~Hz}, \mathrm{CH}_{3}\right) ;{ }^{13} \mathrm{C}-\mathrm{NMR}(75.5$ $\mathrm{MHz}, \mathrm{DMSO}_{\mathrm{d}}$ ) $\delta 172,162,144,139,132,131,130,129$, 126, 124, 103, 65, 64, 61, 42.0, 33, 32, 29.8, 29.7, 29.6, 29.4, 26, 23, 22, 14; IR(neat) $\mathrm{cm}^{-1} 1741(\mathrm{C}=\mathrm{O}), 1723(\mathrm{C}=\mathrm{C})$; Tandem MS $\left(\mathrm{FAB}^{+}\right)$calc $\mathrm{C}_{25} \mathrm{H}_{31} \mathrm{NO}_{3} 394.2384(\mathrm{M}+1)$, observed $394.2382(\mathrm{M}+1)$.

5-Benzoyl-2,3-dihydro-1H-pyrrolizine-1-carboxylic acid cis-7-dodecenate, Y-002 (2)

Ketorolac (70 mg, $0.274 \mathrm{mmol})$ in $\mathrm{CH}_{2} \mathrm{Cl}_{2}(10 \mathrm{~mL})$ with the addition of $N, N$ '-dicyclohexylcarbodiimide $(0.34 \mathrm{~mL}$ of $1.0 \mathrm{M}$ in $\mathrm{CH}_{2} \mathrm{Cl}_{2}, 0.34 \mathrm{mmol}$ ), 4-pyrrolidinopyridine (1 $\mathrm{mg}$ ) and cis7-dodecen-1-ol (100 mg, $0.54 \mathrm{mmol})$ gave the cis-7-dodecen1-ester prodrug $(75 \mathrm{mg}, 64.7 \%)$ as a yellowish oil: UV $(\mathrm{MeOH})) \lambda_{\max } 312 \mathrm{~nm}\left(\log \varepsilon_{\max }=4.05\right) ;{ }^{1} \mathrm{H} \mathrm{NMR}(300 \mathrm{MHz}$, $\left.\mathrm{CD}_{3} \mathrm{OD}\right) \delta$ 7.78-7.48 (5H, m, Ar-H), $6.81(1 \mathrm{H}, \mathrm{d}, \mathrm{J}=4.0 \mathrm{~Hz}$, $\mathrm{CH}=\mathrm{CH}), 6.10(1 \mathrm{H}, \mathrm{d}, \mathrm{J}=4.0 \mathrm{~Hz}, \mathrm{CH}=\mathrm{CH}), 5.34(2 \mathrm{H}, \mathrm{m}$, $\mathrm{CH}=\mathrm{CH}), 4.57-4.40\left(2 \mathrm{H}, \mathrm{m}, \mathrm{NCH}_{2}-\right), 4.24-4.06(2 \mathrm{H}, \mathrm{m},-$ $\left.\mathrm{OCH}_{2}, 1 \mathrm{H},-\mathrm{CH}-\right), 3.00-2.74\left(2 \mathrm{H}, \mathrm{m},-\mathrm{CH}_{2}\right), 2.02-2.13(4 \mathrm{H}, \mathrm{m}$, $\left.-\mathrm{CH}_{2}-\right), 1.00-1.80\left(12 \mathrm{H}, \mathrm{m},-\mathrm{CH}_{2}-\right), 0.88-0.92(3 \mathrm{H}, \mathrm{t}, J=7.4$ $\left.\mathrm{Hz}, \mathrm{CH}_{3}\right) ;{ }^{13} \mathrm{C}-\mathrm{NMR}\left(75.5 \mathrm{MHz}, \mathrm{DMSO}-\mathrm{d}_{6}\right) \delta 185,172,144$, 139, 132, 130, 129(3), 126, 103, 65, 61, 42.0, 33, 32, 30(3), 29, 26(5), 22, 13; IR (neat) $\mathrm{cm}^{-1} 1737(\mathrm{C}=\mathrm{O}), 1721(\mathrm{C}=\mathrm{C})$; Tandem $\mathrm{MS}\left(\mathrm{FAB}^{+}\right)$calc $\mathrm{C}_{27} \mathrm{H}_{35} \mathrm{NO}_{3} 422.2697(\mathrm{M}+1)$ observed $422.2695(\mathrm{M}+1)$.

5-Benzoyl-2,3-dihydro-1H-pyrrolizine-1-carboxylic acid palmitoleyl ester, Y-003 (3)

Ketorolac (500 mg, $1.96 \mathrm{mmol}$ ) in $\mathrm{CH}_{2} \mathrm{Cl}_{2}(10 \mathrm{~mL})$ and $N, N$ '-dicyclohexylcarbodiimide $\left(2.4 \mathrm{~mL}\right.$ of $1.0 \mathrm{M}$ in $\mathrm{CH}_{2} \mathrm{Cl}_{2}$, $2.4 \mathrm{mmol})$, 4-pyrrolidinopyridine $(6 \mathrm{mg})$ and palmitoleyl alco- 
Table II-Physico-chemical Properties of Ketorolac and Its Enhancer-prodrugs

\begin{tabular}{cccccc}
\hline \hline \multirow{2}{*}{ Compound } & Compound code & $\begin{array}{c}\text { Molecular } \\
\text { Weight }(\mathrm{g} / \mathrm{mol})\end{array}$ & Solubility $(\mu \mathrm{g} / \mathrm{mL})$ & \multirow{2}{*}{$\begin{array}{c}\text { Capacity factor } \\
(\operatorname{Log~k})\end{array}$} & Log $P^{a}$ \\
Ketorolac & & 255.27 & $18.17( \pm 0.238) \times 10^{3}$ & -0.68 & 1.64 \\
$\mathbf{1}$ & Y-001 & 393.23 & $5.96( \pm 0.11)$ & 0.143 & 5.33 \\
$\mathbf{2}$ & Y-002 & 421.26 & $4.81( \pm 0.05)$ & 0.347 & 6.16 \\
$\mathbf{3}$ & Y-003 & 477.32 & $3.37( \pm 0.04)$ & 0.705 & 7.83 \\
$\mathbf{4}$ & Y-004 & 505.35 & $0.76( \pm 0.1)$ & 0.88 & 8.67 \\
$\mathbf{5}$ & Y-005 & 395.25 & $5.56( \pm 0.04)$ & 0.29 & 5.65 \\
$\mathbf{6}$ & Y-006 & 423.28 & $5.53( \pm 0.02)$ & 0.45 & 6.48 \\
\hline
\end{tabular}

a. Calculated from Chemdraw ${ }^{\circledR}$

Each data represents the mean $\pm \mathrm{SD}$ of three determinations

hol (1 g, $4.16 \mathrm{mmol})$ gave palmitoleyl ester prodrug (354 mg, $37.8 \%)$ as a yellowish oil: $U V(\mathrm{MeOH}) \lambda_{\max } 313 \mathrm{~nm}\left(\log \varepsilon_{\max }\right.$ $=4.09) ;{ }^{1} \mathrm{H}$ NMR $\left(300 \mathrm{MHz}, \mathrm{CD}_{3} \mathrm{OD}\right) \delta$ 7.78-7.48 (5H, m, Ar$\mathrm{H}), 6.81(1 \mathrm{H}, \mathrm{d}, \mathrm{J}=4.0 \mathrm{~Hz}, \mathrm{CH}=\mathrm{CH}), 6.10(1 \mathrm{H}, \mathrm{d}, \mathrm{J}=4.0 \mathrm{~Hz}$, $\mathrm{CH}=\mathrm{CH}), 5.34(2 \mathrm{H}, \mathrm{m}, \mathrm{CH}=\mathrm{CH}), 4.57-4.40\left(2 \mathrm{H}, \mathrm{m}, \mathrm{NCH}_{2}-\right)$, 4.24-4.06 (2H, m,-OCH $, 1 \mathrm{H},-\mathrm{CH}-)$, 3.00-2.74 (2H, m, $-\mathrm{CH}_{2}$ ), 2.02-2.13 (4H, m, - $\left.\mathrm{CH}_{2}-\right), 1.00-1.80\left(20 \mathrm{H}, \mathrm{m},-\mathrm{CH}_{2}-\right), 0.88-$ $0.92\left(3 \mathrm{H}, \mathrm{t}, J=7.4 \mathrm{~Hz}, \mathrm{CH}_{3}\right) ;{ }^{13} \mathrm{C}-\mathrm{NMR}(75.5 \mathrm{MHz}, \mathrm{DMSO}-$ $\left.\mathrm{d}_{6}\right) \delta 185,172,144,139,132,130,129(3), 126,103,65,61$, 43, 33, 32, 31, 30(3), 29(7), 26(2), 23, 13; IR (neat) $\mathrm{cm}^{-1}$ $1741(\mathrm{C}=\mathrm{O}), 1721(\mathrm{C}=\mathrm{C})$; Tandem $\mathrm{MS}\left(\mathrm{FAB}^{+}\right)$calc $\mathrm{C}_{31} \mathrm{H}_{43} \mathrm{NO}_{3}$ $478.3323(\mathrm{M}+1)$, observed $478.3319(\mathrm{M}+1)$.

5-Benzoyl-2,3-dihydro-1H-pyrrolizine-1-carboxylic acid oleyl ester, Y-004 (4)

Ketorolac $(1.5 \mathrm{~g}, 5.88 \mathrm{mmol})$ in $\mathrm{CH}_{2} \mathrm{Cl}_{2}(30 \mathrm{~mL})$ and $N, N^{\prime}-$ dicyclohexylcarbodiimide ( $9 \mathrm{~mL}$ of $1.0 \mathrm{M}$ in $\mathrm{CH}_{2} \mathrm{Cl}_{2}, 9 \mathrm{mmol}$ ), 4-pyrrolidinopyridine $(13 \mathrm{mg})$ and oleyl alcohol $(5 \mathrm{~g}, 18.6$ mmol) gave the oleyl ester prodrug $(4.12 \mathrm{~g}, 44.1 \%)$ as a yellowish oil: UV (MeOH) $\lambda_{\max } 311 \mathrm{~nm}\left(\log \varepsilon_{\max }=4.12\right)$; ${ }^{1} \mathrm{H}-$ NMR (300 MHz, DMSO-d $)_{6} \delta=7.80-7.70(2 \mathrm{H}, \mathrm{m}, \mathrm{Ar}-\mathrm{H})$, 7.60-7.40 (3H, m, Ar-H), $6.78(1 \mathrm{H}, \mathrm{d}, J=4.0 \mathrm{~Hz}, \mathrm{CH}=\mathrm{CH})$, $6.08(1 \mathrm{H}, \mathrm{d}, J=4.0 \mathrm{~Hz}, \mathrm{CH}=\mathrm{CH}), 5.28-5.32(2 \mathrm{H}, \mathrm{m}, \mathrm{CH}=$ $\mathrm{CH}), 4.52-4.38\left(2 \mathrm{H}, \mathrm{m},-\mathrm{NCH}_{2}-\right), 4.08-4.06\left(2 \mathrm{H}, \mathrm{m}, \mathrm{OCH}_{2}\right)$, 4.04-4.00 (1H, m, -CH-), 2.88-2.68 (2H, m, $\left.-\mathrm{CH}_{2}-\right)$, 1.00-1.80 $\left(28 \mathrm{H}, \mathrm{m},-\mathrm{CH}_{2}-\right), 0.94-0.89$ (3H, t, $\left.J=7.4 \mathrm{~Hz}, \mathrm{CH}_{3}\right) ;{ }^{13} \mathrm{C}-\mathrm{NMR}$ (75.5 MHz, DMSO-d $\left.{ }_{6}\right) \delta=172,164,146,139,132,130,129$, $128,127,124,104,103,77,65,61,47.0,42.0,39,33,32$, 29.8, 29.7, 29.6, 29.4, 26, 22, 14; IR (neat) $\mathrm{cm}^{-1} 1741(\mathrm{C}=\mathrm{O})$; Tandem MS $\left(\mathrm{FAB}^{+}\right)$calc $\mathrm{C}_{33} \mathrm{H}_{48} \mathrm{NO}_{3} 506.3636(\mathrm{M}+1)$, observed $506.3634(\mathrm{M}+1)$.

5-Benzoyl-2,3-dihydro-1H-pyrrolizine-1-carboxylic acid decyl ester, Y-005 (5)

Ketorolac $(0.6 \mathrm{~g}, 2.35 \mathrm{mmol})$ in $\mathrm{CH}_{2} \mathrm{Cl}_{2}(10 \mathrm{~mL})$ and $N, N^{\prime}-$ dicyclohexylcarbodiimide $\left(2.4 \mathrm{~mL}\right.$ of $1.0 \mathrm{M}$ in $\mathrm{CH}_{2} \mathrm{Cl}_{2}, 2.4$ mmol), 4-pyrrolidinopyridine $(4.2 \mathrm{mg})$ and decyl alcohol $(1.2 \mathrm{~mL}, 7.58 \mathrm{mmol})$ gave decyl ester prodrug (693 mg, 74.5 $\%)$ as a yellowish oil: $\mathrm{UV}(\mathrm{MeOH}) \lambda_{\max } 312 \mathrm{~nm}\left(\log \varepsilon_{\max }=\right.$ 3.95); ${ }^{1} \mathrm{H}$ NMR (300 MHz, CD $\left.\mathrm{OD}\right) \delta$ 7.82-7.42 (5H, m, Ar$\mathrm{H}), 6.78(1 \mathrm{H}, \mathrm{d}, J=4.0 \mathrm{~Hz}, \mathrm{CH}=\mathrm{CH}), 6.08(1 \mathrm{H}, \mathrm{d}, J=4.0 \mathrm{~Hz}$, $\mathrm{CH}=\mathrm{CH}), 4.52-4.38\left(2 \mathrm{H}, \mathrm{m},-\mathrm{NCH}_{2}-\right), 4.08-4.06(2 \mathrm{H}, \mathrm{m},-$ $\left.\mathrm{OCH}_{2}\right)$, 4.04-4.00 (1H, m, -CH-), 2.88-2.68 (2H, m, $\left.-\mathrm{CH}_{2}^{-}\right)$, 2.02-2.13 (4H, m, - $\left.\mathrm{CH}_{2}-\right)$, 1.00-1.80 (12H, m, - $\left.\mathrm{CH}_{2}-\right), 0.86-$ $0.92\left(3 \mathrm{H}, \mathrm{t}, J=7.4 \mathrm{~Hz}, \mathrm{CH}_{3}\right) ;{ }^{13} \mathrm{C}-\mathrm{NMR}(75.5 \mathrm{MHz}, \mathrm{DMSO}-$ $\left.\mathrm{d}_{6}\right) \delta 185,172,144,139,132,131,130,129,126,124,103,65$, 64, 61, 42, 33, 31, 30, 29(3), 26, 22, 17,14; IR (neat) $\mathrm{cm}^{-1}$ $1739(\mathrm{C}=\mathrm{O})$; Tandem $\mathrm{MS}\left(\mathrm{FAB}^{+}\right)$calc $\mathrm{C}_{25} \mathrm{H}_{33} \mathrm{NO}_{3}$ 396.2540, observed $396.5517(\mathrm{M}+1)$.

5-Benzoyl-2,3-dihydro-1H-pyrrolizine-1-carboxylic acid dodecan ester, Y-006 (6)

Ketorolac $(0.4 \mathrm{~g}, 1.57 \mathrm{mmol})$ in $\mathrm{CH}_{2} \mathrm{Cl}_{2}(25 \mathrm{~mL})$ and $N, N^{\prime}-$ dicyclohexylcarbodiimide $\left(1.6 \mathrm{~mL}\right.$ of $1.0 \mathrm{M}$ in $\mathrm{CH}_{2} \mathrm{Cl}_{2}, 1.6$ $\mathrm{mmol}), 4$-pyrrolidinopyridine $(2.8 \mathrm{mg})$ and dodecanol $(0.88 \mathrm{~g}$, $4.72 \mathrm{mmol}$ ) gave dodecan ester prodrug (290 mg, 43.9\%) as a yellowish oil: UV (MeOH) $\lambda_{\max } 312 \mathrm{~nm}\left(\log \varepsilon_{\max }=3.97\right) ;{ }^{1} \mathrm{H}$ NMR (300 MHz, CD 3 OD) $\delta$ 7.82-7.42 (5H, m, Ar-H), 6.78 $(1 \mathrm{H}, \mathrm{d}, J=4.0 \mathrm{~Hz}, \mathrm{CH}=\mathrm{CH}), 6.08(1 \mathrm{H}, \mathrm{d}, J=4.0 \mathrm{~Hz}, \mathrm{CH}=$ $\mathrm{CH}), 4.52-4.38\left(2 \mathrm{H}, \mathrm{m},-\mathrm{NCH}_{2}-\right)$, 4.08-4.06 (2H, m, $\left.-\mathrm{OCH}_{2}\right)$, 4.04-4.00 (1H, m, -CH-), 2.88-2.68 (2H, m, $\left.-\mathrm{CH}_{2}-\right)$, 2.02-2.13 $\left(4 \mathrm{H}, \mathrm{m},-\mathrm{CH}_{2^{-}}\right), 1.00-1.80\left(16 \mathrm{H}, \mathrm{m},-\mathrm{CH}_{2}-\right), 0.86-0.92(3 \mathrm{H}, \mathrm{t}$, $\left.J=7.4 \mathrm{~Hz}, \mathrm{CH}_{3}\right) ;{ }^{13} \mathrm{C}-\mathrm{NMR}\left(75.5 \mathrm{MHz}, \mathrm{DMSO}-\mathrm{d}_{6}\right) \delta 185$, $172,144,139,132,131,130,129,126,124,103,65,64,61$, 42, 33, 31, 30, 29(5), 26, 22, 17,14; IR (neat) $\mathrm{cm}^{-1} 1741(\mathrm{C}=$ $\mathrm{O})$; Tandem $\mathrm{MS}\left(\mathrm{FAB}^{+}\right.$) calc $\mathrm{C}_{27} \mathrm{H}_{37} \mathrm{NO}_{3}$ 424.2853, observed $424.2852(\mathrm{M}+1)$.

\section{Physico-chemical characteristics}

The physico-chemical properties including capacity factor 


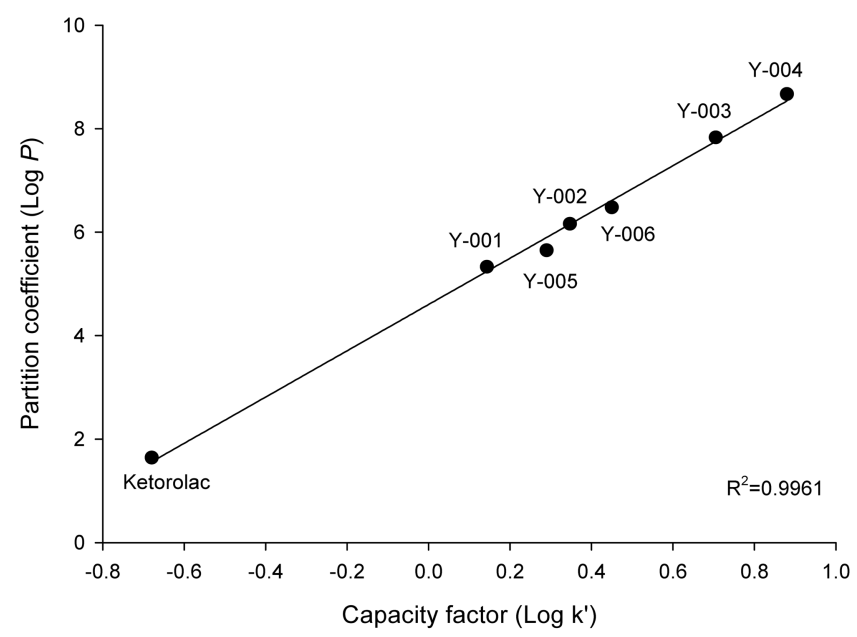

Figure 1-Relationship between the partition coefficients and capacity factors of Ketorolac and its enhancer prodrugs.

(k') of Ketorolac and its ester prodrugs are shown in Table II. The molecular weights of Ketorolac and its prodrugs ranged from 393 to $506 \mathrm{~g} / \mathrm{mol}$. Lipophilicity of Ketorolac and its ester prodrugs were determined in terms of partition coefficient $\left(\log P\right.$ ) by using ChemDraw ${ }^{\circledR}$ and capacity factor $\left(k^{\prime}\right)$ by running an HPLC analysis. The $\log P$ values of the ester prodrugs ranged from 5.33 to 8.67. The plot of $\log P$ versus capacity factor showed a good linear relationship with a correlation coefficient of 0.9961 (Figure 1). Thus, determining the capacity factors instead of the $\log P$ values may be a more convenient alternative to estimating the lipophilicity of future analogs. As shown in Table II, the solubility of ester prodrugs in $10 \% \mathrm{PG} / \mathrm{IPB}$ ranged from 0.76 to $5.96 \mu \mathrm{g} / \mathrm{mL}$. All prodrugs were poorly soluble in aqueous solution and as expected, the $\log P$ value of the ester prodrugs were higher when the carbon chain length of the prodrugs were longer.

\section{Stability of Ketorolac ester prodrugs}

The hydrolysis of Ketorolac prodrugs in $10 \% \mathrm{PG} / \mathrm{IPB}$, in skin extract, and in plasma was evaluated at $37^{\circ} \mathrm{C}$ as show in
Figure 2. Because all alkyl ester prodrugs were poorly soluble in aqueous vehicles, $10 \%$ PG was added to solubilize the prodrugs in IPB. In $10 \%$ PG/IPB, which was an environment devoid of the presence of esterases, all six compounds degraded slowly over a 12 hour period. The degradation followed a first order kinetics as shown in Figure 2a. In the absence of esterases, as the carbon chain length of the ester moiety increased, the half-life of the compounds decreased (Table III). In other words, compounds with longer ester moieties degraded faster. However, in the case of compounds 5 and $\mathbf{6}$ which were of the same chain length as compounds $\mathbf{1}$ and 2 respectively, a different pattern was observed. The saturation of the ester moiety resulted in a much more stable compound as shown in the half-lives of 21.86 and 49.5 hour respectively. It may thus be helpful to have an unsaturated group in the ester chain for the purpose of developing enhancer-prodrugs since it is crucial that they hydrolyze in the skin before penetration.

In the presence of esterases, the hydrolysis pattern was different. In skin extract, the degradation of the analogues was faster than in $10 \%$ PG/IPB. The degradation also followed a first order kinetics (Figure 2b). The half life was shortest for compound 2. As the alkyl chain increased, a decrease in halflife was observed until $\mathrm{C}-12$ but increased again as the chain elongated to C-16 and C-18 (Table III). For unsaturated compounds, $\mathbf{5}$ and $\mathbf{6}$, longer half-lives were observed compared to their unsaturated counterparts $\mathbf{1}$ and $\mathbf{2}$ respectively although they were not as stable as in the $10 \%$ PG/IPB. A similar pattern was observed in plasma (Figures 2c) as in the skin extract. However, the overall stability was greater in plasma compared to that in skin extract, which was quite encouraging for enhancer-prodrug candidates. The half-lives of the enhancerprodrugs ranged from 9.04 to 49.5 hours in $10 \%$ PG/IPB. In the skin extract, half-life ranged from 0.96 to 8.04 hours and in plasma from 2.97 to 8.48 hours (Table III). Further studies are however needed to find the rationale as to why these prodrugs

Table III-Half-lives ( $\left.t_{1 / 2}\right)$ of Ketorolac Ester Prodrugs in 10\% PG/IPB, in Skin Extract and in Plasma at $37^{\circ} \mathrm{C}$

\begin{tabular}{|c|c|c|c|c|c|}
\hline \multirow{2}{*}{ Compound } & \multirow{2}{*}{ Carbon chain } & \multirow{2}{*}{ \# of double bond } & $10 \% \mathrm{PG} / \mathrm{IPB}$ & Skin extract & 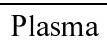 \\
\hline & & & $\mathrm{t}_{1 / 2}(\mathrm{hr})$ & $\mathrm{t}_{1 / 2}(\mathrm{hr})$ & $\mathrm{t}_{1 / 2}(\mathrm{hr})$ \\
\hline 1 & $\mathrm{C}_{10}$ & 1 & 16.94 & 1.05 & 5.26 \\
\hline 2 & $\mathrm{C}_{12}$ & 1 & 13.22 & 0.96 & 2.97 \\
\hline 3 & $\mathrm{C}_{16}$ & 1 & 11.23 & 3.03 & 8.48 \\
\hline 4 & $\mathrm{C}_{18}$ & 1 & 9.04 & 8.04 & 8.19 \\
\hline 5 & $\mathrm{C}_{10}$ & 0 & 21.86 & 4.32 & 5.62 \\
\hline 6 & $\mathrm{C}_{12}$ & 0 & 49.5 & 7.83 & 5.48 \\
\hline
\end{tabular}

Half-life $\left(\mathrm{t}_{1 / 2}\right)$ was obtained by $\mathrm{t}_{1 / 2}=\ln 2 / \mathrm{k}$. Constant $\mathrm{k}$ was obtained from the slope of $\operatorname{lnC}$ vs time plot. 


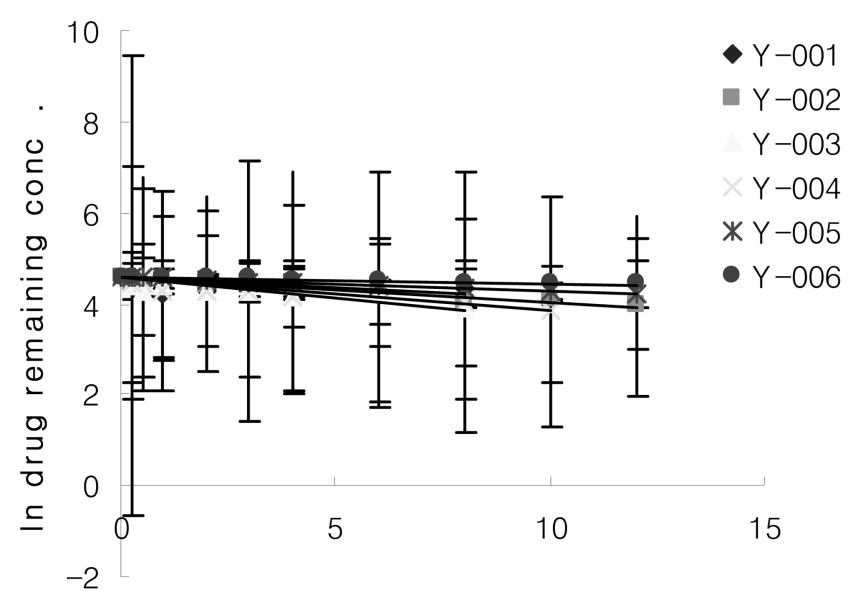

Time $(h r)$

(a)

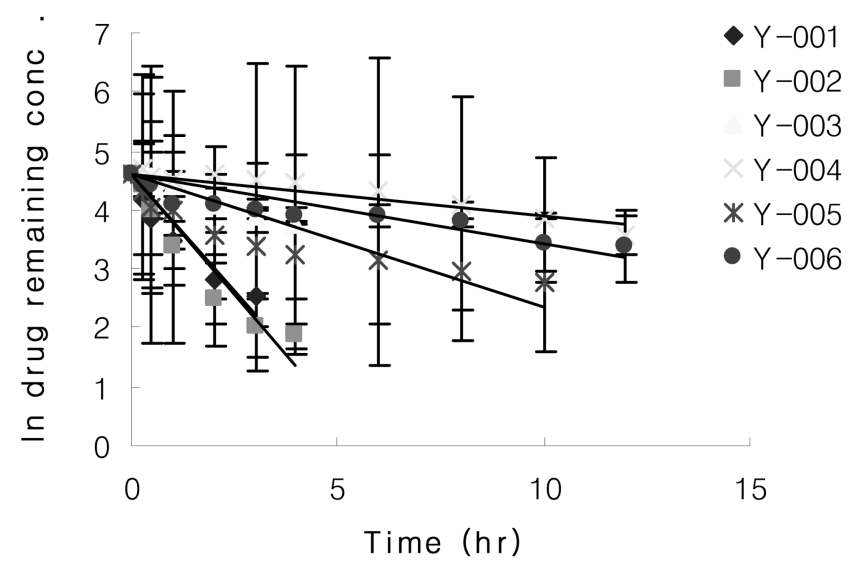

(b)

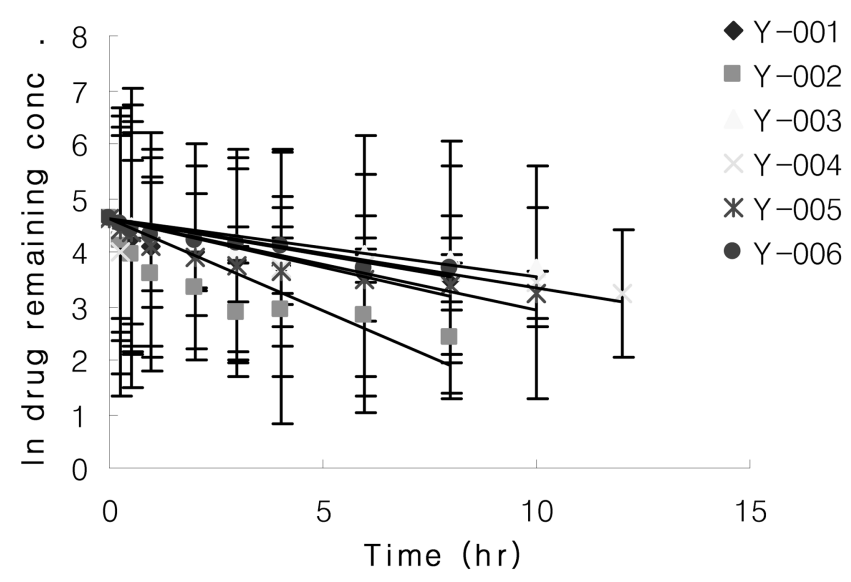

(c)

Figure 2-Stability as \% drug remaining over 12 hours at $37^{\circ} \mathrm{C}$ of Ketorolac ester prodrugs (a) in 10\% PG/IPB (pH 7.4), (b) in skin extract, (c) in plasma.

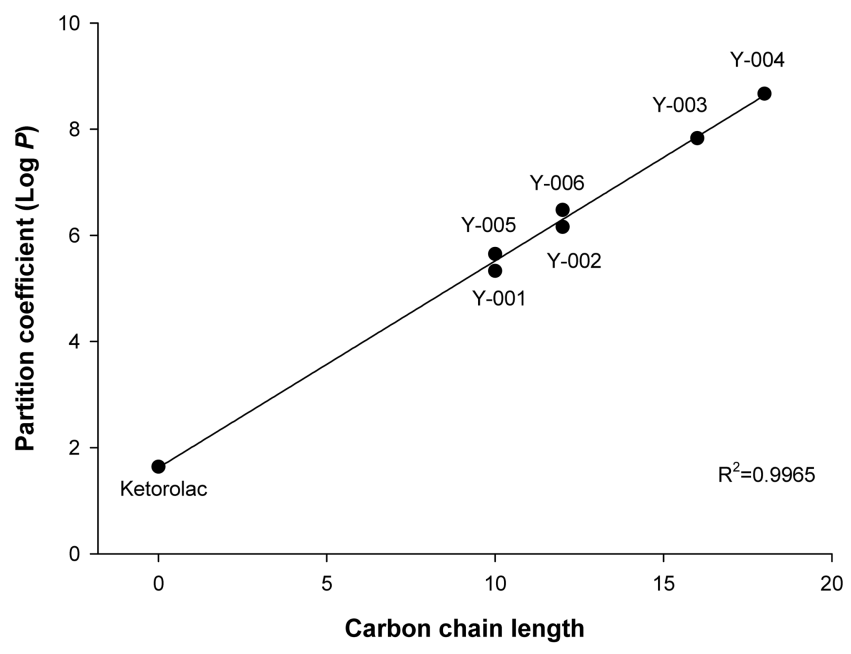

Figure 3-Relationship between the partition coefficient and carbon chain length of ketorolac and its esters.

behave differently in $10 \%$ PG/IPB compared to skin extract and plasma.

\section{Structure-Activity Relationship}

A systematic SAR study was performed. As shown in Figure 3 good correlation between the carbon chain length of the ester moieties and partition coefficients $(\log P)$ was observed. Except for compounds $\mathbf{5}$ and $\mathbf{6}$, all prodrugs contained one double bond in the ester moiety. However, as show in Figure 3 only a marginal difference in lipophilicity resulted between compounds $\mathbf{1}$ and $\mathbf{5}$ and between compounds $\mathbf{2}$ and $\mathbf{6}$ where the saturated ester linkage tended to be slightly more lipophilic.

The correlation between the percent degradation of prodrugs

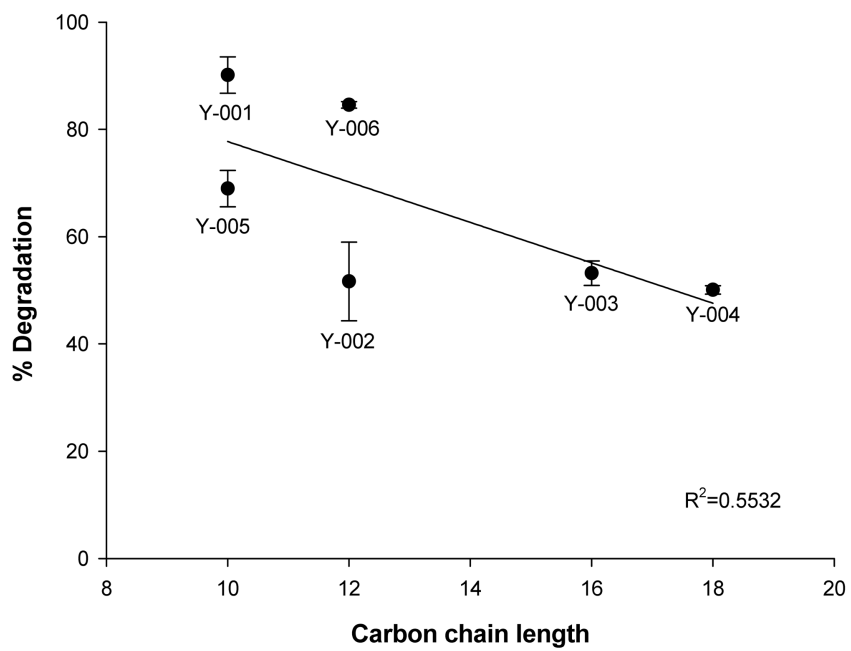

Figure 4-Correlation between percent degradation after 12 hours and the carbon chain length of the ester moiety in the $10 \% \mathrm{PG} / \mathrm{IPB}$. 


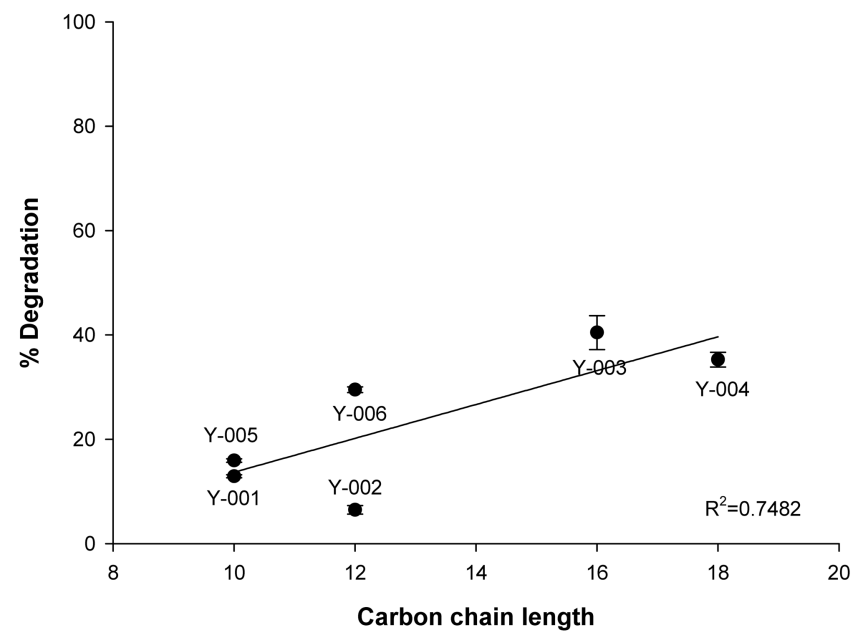

Figure 5-Correlation between percent degradation after 12 hours and the carbon chain length of the ester moiety in the skin extract.

and the carbon chain length of the ester moiety after 12 hours in $10 \% \mathrm{PG} / \mathrm{IPB}$, in skin extract and in plasma was examined. As shown in Figure 4, the percent degradation in $10 \%$ PG/IPB moderately correlated with the carbon chain length of the ester moiety after 12 hours $\left(\mathrm{R}^{2}=0.5532\right)$. Esters of longer chain length seemed to have degraded more slowly than those with shorter chain lengths. However, the overall range of degradation between these analogues seemed very narrow and therefore it would be difficult to draw a solid conclusion based on this data alone. In the skin extract, better correlation was observed between the percent degradation at 12 hours (Figure $5, \mathrm{R}^{2}=0.7482$ ) and the carbon chain length. The longer the chain length, the faster was the degradation. However, in plasma, no significant correlation was observed (Figure 6, $\left.\mathrm{R}^{2}=0.0621\right)$ after 12 hours.

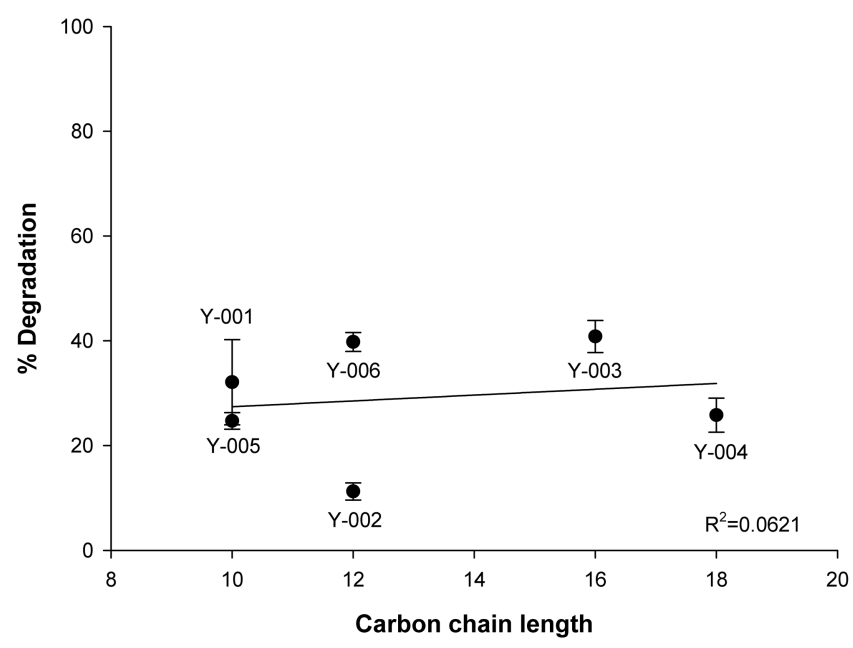

Figure 6-Correlation between percent degradation after 12 hours and the carbon chain length of the ester moiety in the plasma.

\section{Conclusions}

Ketorolac enhancer-prodrug candidates were synthesized in good yield. The lipophilicity of prodrugs increased as the carbon chain length increased and the capacity factors of the analogues correlated well with the calculated $\log P$ values $\left(\mathrm{R}^{2}=0.9961\right)$. In terms of stability, the enhancer prodrugs slowly degraded in a non-enzymatic environment such as in $10 \%$ PG/IPB solution. The longer chained esters had shorter half-lives than the shorter chained ones but all were fairly stable over a 12 hour period. In the skin extract, the enzymatic degradation facilitated the hydrolysis of esters. The hydrolysis was fastest for the C-12 analogue, 2, but slowed down as the carbon chain elongated to $\mathrm{C}-18$. Unsaturation seemed to facilitate the degradation as compared to the saturated analogues. In plasma, degradation was slower than in the skin extract, which is a desirable trait for enhancer-prodrugs. However, the overall hydrolysis in skin extract has to be faster for the analogues to be effective enhancer prodrugs. The significance of this work is in providing structure-stability relationship results, which could facilitate further studies to design and develop Ketorolac enhancer prodrugs.

\section{Acknowledgements}

This work was supported by the Korea Research Foundation Grant KRF-2004-E00172.

\section{References}

1) D.J. Dula, R. Anderson and GC. Wood, A prospective study comparing i.m. ketorolac with i.m. meperidine in the treatment of acute biliary colic, J Emeg Med., 20, 121-124, (2000).

2) A.C. Guidera, J.I. Luchs and I.J. Undell, Keratitis, ulceration, and perforation associated with topical nonsteroidal antiinflammatory drugs. Ophthalmology, 108, 936-944, (2001).

3) M.M. Buckley and R.N. Brogden, Ketorolac: a review of its pharmacodynamic and pharmacokinetic properties, and therapeutic potential. Drugs., 39, 86-109, (1990).

4) D.I. Reinhart, Minimising the adverse effects of ketorolac. Int.J. Med., Toxi Drug Exper, 22, 487-497, (2000).

5) D. Yu, L.M. Sanders, GW.R. Davidson III, M.J. Marvin and T. Ling, Percutaneous absorption of nicardipine and ketorolac in rhesus monkeys. Pharm. Res., 5, 457-462, (1988).

6) S.D. Roy, E. Manoukian, D.J. Combs and Absorption of transdermal delivered ketorolac acid in humans. J. Pharm. Sci., 84, 49-52, (1995).

7) S.D. Roy and E.J. Manoukian, Transdermal delivery of ketorolac tromethamine: permeation enhancement device design, and pharmacokinetics in healthy humans. J.Pharm. Sci., 84, 
1190-1196, (1995).

8) H.J. Doh, W.J. Cho, C.S. Yong, H.G. Choi, J.S. Kim, C.H. Lee and D.D. Kim, Synthesis and evaluation of ketorolac ester prodrugs for transdermal delivery. J.Pharm. Sci., 92, 1008-1017, (2003).

9) E. Boelsma, H. Tanojo, H.E. Bodde, M. Ponec and Assessment of the potential irritancy of oleic acid on human skin; evaluation in vitro and in vivo. Toxicol. In Vitro, 10, 729-742, (1996).

10) P.G Green, P.H. Guy and J. Hadgraft. In vitro and in vivo enhancement of skin permeation with oleic and lauric acid. Int. J. Pharm, 48, 103-111, (1988).

11) P. Ettmayer, GL. Amidon, B. Clement and B. Testa, Lessons learned from marketed and investigational prodrugs. J. Med. Chem., 47, 2393-2404, (2004).

12) S.D. Roy and E.J. Manoukian, Permeability of ketorolac acid and its ester analogs (prodrug) through human cadaver skin. $J$. Pharm. Sci., 83, 1548-1553, (1994).

13) S. Bal-Tembe, D.N. Bhedi, N.J. De Souza and R.H. Rupp, Synthesis of ( \pm )-praeruptorin A and related khellactone derivatives. Heterocycles., 29, 1239-1249, (1989).

14) J.S. Kim, Q. Sun, B. Gatto, C. Yu, A. Liu, L.F. Liu and E.J. Lavoie, Structure-Activity Relationships of Benzimidazoles and Related Heterocycles as Topoisomerase I Poisons, Bioorganic \& Medicinal Chemistry., 4(4), 621-630, (1996). 